\title{
LACTIC DEHYDROGENASE AND TRANSAMINASES IN BOVINE EPIDIDYMAL FLUID*
}

\author{
O. T. STALLGUP, G. J. BROWN AND W. T. COLE \\ Department of Animal Sciences, University of Arkansas, Fayetteville
}

(Received 14th August 1967, revised 30th October 1967)

The activity of the enzyme lactic dehydrogenase (LD) in bovine blood serum (Roussel \& Stallcup, 1965a) and in semen (Roussel \& Stallcup, 1965c), and of glutamic-oxalacetic transaminase (GOT) and glutamic-pyruvic transaminase (GPT) in bovine blood serum (Roussel \& Stallcup, 1965b) and semen have been previously reported and the literature reviewed (Flipse, 1960; Gregoire, Rakoff \& Ward, 1961; Roussel \& Stallcup, 1965d). The activity of the transaminases in the epididymal fluid of the ram has been reported by Alumot \& Schindler (1965). The experiments reported here were undertaken to measure the activities of LD, GOT and GPT in bovine epididymal fluids compared to their activity in blood serum.

Eight Aberdeen-Angus bulls, 14 months of age, were used in these studies. All animals were from the herds of the Arkansas Agricultural Experiment Station, and a complete life history as to age, diet and management practices was available in connection with research concerned with animal breeding. Blood samples were obtained from the jugular vein of each bull 1 week before slaughter, transferred to screw cap vials, and cooled; after coagulation they were centrifuged at $1000 \mathrm{~g}$ for $25 \mathrm{~min}$ at $5^{\circ} \mathrm{C}$. The activity of serum LD was estimated by the method of Berger \& Broida (1958) and serum GOT and GPT by a colorimetric procedure of Reitman \& Frankel (1957). The LD activity is expressed as Berger-Broida units. The unit is equivalent to that amount of enzyme associated with a decrease in optical density at $340 \mathrm{Mu}$ of $0.001 / \mathrm{min}$ in a reaction mix of $3 \mathrm{ml}$ volume, as described by Wrobleswki \& LaDue (1955).

When the animals were killed, samples of epididymal semen $(0.3$ to $0.6 \mathrm{ml})$ were obtained by careful dissection and puncture of region ' $F$ ' of the cauda epididymidis, using the procedure described by Crabo \& Gustafsson (1964). The samples of epididymal semen were then centrifuged with equal volumes of $0.075 \mathrm{M}$ phosphate buffer, $\mathrm{pH} 6 \cdot 8$, and the supernatant diluted with 5 volumes of distilled water. The diluted fluid was then used for enzyme assays. The methods used were those cited previously for blood serum.

It can be seen from Table 1 that the activity of LD in the epididymal fluid was more than twice that in blood serum. Histochemical localization of the enzyme in previous studies indicated LD activity in the epithelial cells lining various segments of the epididymal canal (Stallcup \& Roussel, 1965).

The activity of GOT in epididymal fluid was more than six times greater than in the blood serum. The GPT concentration in epididymal fluid was almost

* Published with the approval of the Director of the Arkansas Agricultural Experiment Station. 
twice that found in the blood serum, but its activity was quite variable in both epididymal fluid and blood serum.

The values of enzyme activity in epididymal fluid may be compared to values in seminal plasma of $1853 \pm 40,262 \pm 76$ and $10 \pm 3$ units/ml for LD, GOT and GPT, respectively, in other animals of the same age and breed (Stallcup \& Brown, unpublished data). Thus it appears that the LD activities of blood and seminal plasma are similar but less than in epididymal fluid, whereas GPT is higher in epididymal fluid and seminal plasma than in blood plasma. The GPT

TABLE 1

LAGTIC DEHYDROGENASE AND TRANSAMINASE ACTIVITY IN BULL EPIDIDYMAL FLUID AND BLOOD SERUM (MEAN \pm S.E., UNITS/ML, EIGHT ANIMALS)

\begin{tabular}{l|c|c|c}
\hline \multicolumn{1}{c|}{ Fluid } & $L D$ & $G O T$ & $G P T$ \\
\hline Epididymal fluid & $\begin{array}{r}3860 \pm 16 \\
\text { Blood serum }\end{array}$ & $\begin{array}{r}410 \pm 66 \\
80 \pm 10\end{array}$ & $\begin{array}{r}40 \pm 6 \\
21 \pm 7\end{array}$ \\
\hline
\end{tabular}

Activities for LD are given as Berger-Broida (1958) units/ml and for GOT and GPT as Reitman \& Frankel (1957) units/ml.

activity in epididymal fluid is almost twice that found in blood serum and four times that found in seminal plasma. It appears then that the epididymal fluid is one of the sources of both GOT and GPT in the seminal plasma.

The fact that the activity of GOT in the epididymal fluid is several times higher than that found in the blood, points to the possible existence of a transaminase mechanism in the epididymal fluid, independent of that in the blood. This phenomenon has been reported previously in epididymal fluid of the ram (Alumot \& Schindler, 1965). The possibility of leakage from spermatozoa and/or epithelial cells of the epididymis should be taken into account in any hypothesis designed to explain these observations. No attempt was made in this study to secure information on leakage from cells as a source of enzyme activity.

The authors acknowledge the assistance of Mrs Ella Nora Griffon in carrying out this research. This research was financed in part by a grant from the National Association of Animal Breeders, Columbia, Missouri, U.S.A.

\section{REFERENCES}

Alumot, E. \& Schindler, H. (1965) Transaminases in the epididymal fluid of the ram. F. Reprod. Fert. 10, 261.

Berger, L. \& BROIDA, D. (1958) The colorimetric determination of lactic dehydrogenase in serum or other fluids at 400 to $500 \mathrm{Mu}$. Tech. Bull. 500, Sigma Chemical Company, St. Louis, Mo.

Crabo, F. \& Gustafsson, F. (1964) Distribution of sodium and potassium and its relation to sperm concentration in the epididymal plasma of the bull. F. Reprod. Fert. 7, 337.

Furpse, R. J. (1960) Metabolism of bovine semen. IX. Glutamic-oxalacetic and glutamic-pyruvic transaminase activities. 7. Dairy Sci. 43, 773.

Gregorre, A. T., RAKoff, A. E. \& WARD, K. (1961) Glutamic-oxalacetic transaminase in semen of human, bull, and rabbit seminal plasma. Int. F. Fert. 6, 73.

Reitman, S. \& Frankel, S. (1957). Colorimetric method for the determination of serum transaminase activity. Am. F. clin. Path. 28, 56. 
Rousser, J. D. \& Stallgup, O. T. (1965a) Effect of age on lactic dehydrogenase activity in blood serum of Holstein bulls. 7. Dairy Sci. 48,840 .

Roussec, J. D. \& Stallaup, O. T. (1965b) Influence of age on transaminase and phosphatase in male Holstein blood serum. F. Dairy Sci. 48, 841.

Roussel, J. D. \& Stallgup, O. T. (1965c) Activity of lactic dehydrogenase and its isozymes in bovine semen. 7. Dairy Sci. 48, 1506.

Roussel, J. D. \& Stallcup, O. T. (1965d) Parallelism between semen characteristics and glutamicoxalacetic transaminase, glutamic-pyruvic transaminase activities. 7. Dairy Sci. 48, 1684.

Stallcup, O. T. \& Roussel, J. D. (1965) Development of the lactic dehydrogenase enzyme system in the testes and epididymis of young dairy bulls. F. Dairy Sci. 48, 1511.

Wroblewski, F. \& LaDur, J. S. (1955) Lactic dehydrogenase activity in blood. Proc. Soc. exp. Biol. Med. 90, 219. 